\title{
The Level of Sport Culture Among the Students of Al-Hussein Bin Talal University
}

\author{
Dr. Ibrahim Atallah AL-Ja'afreh (Corresponding author) \\ Assistant Professor in Curriculum and Teaching Methods in Physical Education \\ AL-Hussein Bin Talal University - Jordan
}

Received: October 6, 2018 Accepted: November 6, 2018 Published: December 15, 2018

doi:10.5296/ijld.v9i1.13739 URL: https://doi.org/10.5296/ijld.v9i1.13739

\begin{abstract}
This study aimed at identifying the level of sports culture among the students of Al-Hussein Bin Talal University in Jordan in the light of the study's variables (gender, college). To achieve the study's objectives, the researcher used the descriptive approach for its suitability to this type of studies. A questionnaire has been used as a tool to collect data and to measure the level of sports culture among the students of Al-Hussein Bin Talal University. The questionnaire has been divided into four domains (the cognitive domain, health domain, social domain, and the psychological domain). The study's population composed of the first, second, and third-year-students (3850) male and female students. A random sample has been chosen, made of (214) male and female students. The appropriate statistical measures have been used to analyze the results. The results showed that sports culture among the students of Al-Hussein Bin Talal University was of high level in the health and social domains at $(\alpha=0.05)$, they also showed that sports culture was of medium level in the cognitive and psychological domains at $(\alpha=0.05)$. The results demonstrated as well that there are no statistically significant differences at $(\alpha=0.05)$ for the variables of gender and college. The researcher recommended the need to encourage students to practice sports and the importance of the provision of stadiums and sports facilities at the university as well as the allocation of places for females to practice sports activities at the university.
\end{abstract}

Keywords: Sports culture, the students, Al-Hussein Bin Talal University.

\section{Introduction}

Sport is one of the basis on which societies depend to express their past, present and future. It reflects their lifestyle and behavioral patterns; it organizes their members' life and behavior. Culture is progressive and learned from one generation to another through communication and interaction. Culture is humanitarian by nature i.e. related to the human being without other 
creatures. It reflects the society's heritage, values, customs and traditions, as for each society has its own culture that distinguishes it from others (Bahbahani, 1997). Filali, (2014) clarified the style that people follow in their lives depends on the nature of the prevailing culture in the society.

Sports culture is an integral part of the general culture and is not less important than other cultures. Sports culture is shaped by people's lifestyle; the higher the individuals' culture is the more elevated the society is in all fields. Sports culture influences the human movement as for it is closely related to other sciences such as health science, movement science, sociology, psychology and anatomy, besides other sciences that affect people's lives, so they live healthy and happily. (Abd Al-'ati \& Abd AL-Haleem, 2000) defined sports culture as one of the general culture's types which depends on the broad culture that is based on the different aspects of human knowledge, it is an intellectual culture specialized in the sport domain and cannot be reached except by relying on other specialized cultures such as health, artistic, social, sport cultures etc. Sports culture is an integral part of the general culture. It seeks promoting awareness among communities and providing them with positive qualities.

(Al-Zayoud, 2013) defines sports culture as the individuals' set of sport and health information including the values, beliefs, attitudes and opinions related to the field of health and sport. Sports culture includes several healthy behaviors and sporty habits and values as well as the awareness of the knowledge related to sport activity (Qadumi \& Al-'amd, 2017).

The university environment is a fertile environment for the development of the students' mental, social, psychological and educational aspects through the acquisition of various experiences during their university study. This is reflected in the formation of their personality and capabilities to form their relationships properly in order to succeed in the future the way they aspire and achieve their goals (Cornelius, 1995). No doubt that cultural factors have a significant impact on the participation in sport activities, especially for females, as for the university in which the study was conducted is located in a conservative area forming an obstacle for the participation in sport activities at the university, as well as causing the lack of females' participation in sport activities at school where their sports culture can be shaped at an early age.

\subsection{The Significance of the Study}

The importance of the study emerges from the fact that it is one of the few researches that handled the subject of sports culture addressing a very important segment in the society, namely the university students' segment. Its importance lies in identifying the level of sports culture among the students of Al-Hussein Bin Talal University in Jordan. It highlights the strengths and weaknesses in the level of sports culture among the students. It provides decision makers with a general perception concerning the level of sports culture among the university students in order to enhance the strengths and fix the defects. It also paves the way for researchers to address the level of culture in other aspects.

\subsection{Objectives of the Study}

This study aims at achieving the following objectives: 


\section{Macrothink}

1- Identify the level of sports culture among the students of Al-Hussein Bin Talal University in Jordan.

2- Identify the difference in the level of sports culture between males and females.

3- Identify the difference in the level of sports culture between the scientific and the humanitarian colleges.

\subsection{The Problem of the Study}

Sports culture is considered one of the general culture's pillars, formed through the scientific experiences at the university. It greatly influences the formation of the university student's personality regarding the mental, health, psychological and social aspects to enable them to acquire a balanced personality. In the view of the diversity of the students' backgrounds preceding their enrolment at the university, shown in their different customs, traditions, social levels, intellectual affiliations and environment, which influences the sports culture; moreover, the researcher's observation of the lack of females' participation in sports activities pushed the researcher to study this problem to identify the level of sports culture among university students as well as to study the difference according to the variables of gender and college whether scientific or humanitarian. This study seeks to answer the following questions:

1- Identify the level of sports culture among the students at Al-Hussein Bin Talal University in Jordan.

2- Identify the differences in the level of sports culture according to the variables of gender and college.

\subsection{Questions of the study}

1)- What is the level of sports culture among the students at Al-Hussein Bin Talal University in Jordan?

2)- Are there statistically significant differences in the level of sports culture among the students according to the variable of gender?

3)- Are there statistically significant differences in the level of sports culture among the students according to the variable of college whether scientific of humanitarian?

\subsection{Definitions of Terms}

Culture: is the combination of knowledge, information, experiences and traditions that an individual acquires from the surrounding environment in all the health, educational, mental, physical, social, psychological and athletic fields.

Sports culture: is the combination of information, knowledge and accumulated experiences that individuals acquire by practicing sport and perform their role more efficiently in the surrounding environment which individuals find themselves and integral part of it.

\section{Literature Review}

Literature and previous studies dealt with the societies' general culture which reflects the 
individual's customs, traditions and behavior. Thus, culture is the overall of the humanitarian customs and traditions and all the society's knowledge, ideas, ethics, values and beliefs offered to its individuals to adapt and learn. Malinowski described culture as structure that includes knowledge, beliefs, art, ethics, law customs and anything that a human acquires as a member of a society (Kush, 2002). Culture was defined by UNESCO, (1982) as all the spiritual, materialistic, intellectual and emotional characteristics that distinguishes a particular society or social group, they include arts, literatures and lifestyles as well as basic human rights, values systems and beliefs (Al-Rumaihi; Muhammad, 1992). Abd Al-Haleim, (2000) said that culture is a dynamic continuation characterized with movement and the effectiveness of human experiences found during the human existence on earth. As for culture includes all the society's cultural pillars, sports culture is one of these pillars forming an integral part of culture itself. Moreover, the practice of sports activities and its consequences depend on the culture of the individual and society and on the individuals' cognitive structure. Sports activity has become a necessity for its contribution to the balanced growth of individuals which is reflected on the society to become a society that has all the good life elements.

\subsection{Sports Culture Domains}

1)- The cognitive domain: it is all the athletic information related to rules, games and arbitration in the athletic field.

2)- The educational domain: it is all what is related to preparing an individual for life in all the physical, health, psychological, social, mental and moral aspect through the athletic field.

3)- The health domain: it is the individual's ability to mind his body and meet its organic needs to feel healthy.

4)- The social domain: it is to seek teaching individuals the acceptable social behavior, raising their awareness toward sport and providing them with the athletic information that will form their cultural environment.

The importance of sports culture emerges from: (Shhadeh, 2009), (Sadeq, 1990).

1)- Seeking to spread the athletic awareness among communities.

2)- Helping individuals to acquire different useful experiences during their study.

3)- Structuring restful athletic trends based on scientific cognitive basis.

By viewing the previous similar studies and to achieve the study's objectives, the researcher presents some previous similar studies related to sports culture.

Lahlouh, (2017) conducted a study aiming at identifying the role of media in spreading sports culture among the Palestinian universities' students in the West Bank. The researcher used the descriptive approach to achieve the study's objectives. She used a questionnaire as a tool to collect data. A random sample has been chosen composed of (611) students, males and females, from the scientific and humanitarian colleges at the Palestinian universities. The study reached a set of results among which: media has a role of medium level in spreading the sports culture. Moreover, there were statistically significant differences regarding the variable of university as 
well as there were statistically significant differences for the variable of college in favor of the humanitarian colleges. The researcher recommended the importance of minding qualitative and quantitative media programs and hosting seminaries about the importance of sport at the Palestinian universities.

Qadumi \& Al-'amd, (2017) conducted a study that aimed at identifying the level of sports culture and its relationship with the athletic identity among the students of physical education at Al-Najah National University. The researchers used the descriptive approach. A scale of sports culture has been used as the study's tool. A random sample has been chosen composed of (152) students, males and females, studying physical education. The results of the study concluded that sports culture was of a very high level among the sample students, moreover; there were statistically significant differences regarding the athletic identity in favor of males, and there were no statistically significant differences in the level of sports culture attributed to the variables of gender and school year. The researchers recommended to concentrate on the female students' participation in the school sport activities.

Khuayleh, (2016) conducted a study aiming at identifying the level of health and sports culture among the supervisors of education working at the Ministry of Education. The researcher used the descriptive approach. She applied a questionnaire as the study's tool, divided into four domains (health, physical structure, nutrition, sports activity practice) in order to measure the level of sports culture among the educational supervisors. The study sample was chosen purposefully (30) supervisors, males and females, working in the Directorate of education working in the Ministry of Education in the Marqa District. The results showed that the sample members had a medium level on the scale as a whole; the health domain was of high level, sports activity practice was of medium level in the last rank. There were no statistically significant differences at the level of sports culture attributed to the variables of (gender, academic level, and years of experiences). The study recommended encouraging supervisors to practice sports activities and to conduct agreements between the Ministry of Education, sports clubs and universities to practice sports activities during a precise timing.

Aburrab, (2016) conducted a study that aimed at identifying the level of sports culture and the tendency toward participating in sports activities among the students of Al-Najah National University and determining the relationship between the two. The researcher used the descriptive approach to achieve the study's objectives. She used a questionnaire as a tool to collect data. A random sample has been chosen composed of (293) students. The results of the study showed that sports culture among students was of a very high level, and there were no statistically significant differences attributed to the variables of gender and school year. There were statistically significant differences between the scientific and humanitarian colleges in favor of the humanitarian colleges. The most important recommendation of the study was to mind the free courses like the course of physical education, sports culture and nutrition.

Al-Zayoud, (2013) conducted a study aiming at identifying the role of watching sports TV channels in spreading sports culture among the students of Yarmouk University. The researcher used a questionnaire as a tool for the study; it was made of four domains (the cognitive domain, social domain, educational domain, and health domain). The study sample 
was made of the second and third-year-students except those who are studying physical education at Yarmouk University, the sample composed of (327) students. The most important results were that there were statistically significant differences in spreading sports culture in the cognitive, educational and social domains in favor of the scientific colleges. The study also showed that there were statistically significant differences for the variable of gender in favor of males. The study recommended the importance of caring for the quality of sports programs on TV sport channels and to interview the local experts and distinguished players.

Ahmad \& Ismael, (2012) conducted a study that aimed at identifying sports culture and its relation to the social and psychological harmony among fifth-year-students in the Teachers Institute in Diyala district. The researchers used the descriptive approach and they applied a questionnaire as the tool of the study over a random sample composed of (75) students. The most important results were that there were statistically significant differences in the level of culture in favor of students of physical education. The researchers recommended the importance of spreading sports culture among students for all types of games.

Mash'al, Al-Rahahleh \& Batayneh, (2012) carried out a study aiming at identifying the cognitive outcome of nutritional culture and the level of aerobic fitness among the students of physical education at the University of Jordan. The researchers used the descriptive approach to achieve the study's objectives. They applied a questionnaire as a tool to collect data over a random sample composed of (251) students, males and females. The questionnaire composed of four domains (Dietary advice, food group, food selection, and health problems). The study concluded that there was a lack of the nutritional culture and that there was no correlation between nutritional culture and aerobic fitness. The researchers recommended the importance of minding the nutritional culture and making it part of the educational curriculums.

Al-Udwan, (2011) conducted a study that aimed at identifying the role of Jordanian TV in increasing sports culture from the perspective of PE students at the Jordanian universities. The researcher used the descriptive approach to achieve the goals of the study. A questionnaire has been used as a tool to collect data; a random sample has been chosen composed of (319) students, males and females, at Mutah University, the University of Jordan, and Yarmouk University. The study concluded that most of the sample members watch the Jordanian TV programs with a high level, the majority of the sample members prefer watching sports programs and that these programs participate in greatly enhancing their sports culture.

Bani Ata, (2009) carried out a study that aimed at identifying the level of sports culture among the students of the University of Jordan in the health, psychological, social, fitness, information domains. The researcher used the descriptive approach, a random sample has been chosen composed of (692) students, a scale made of (50) questions was prepared based of multiple choices and true or false statements. The results showed that students had a good level of health domain, a medium level for the psychological and social domains, a law level for the domain of fitness, and that students had lack of information. The results showed that the humanitarian collages' students surpassed all the scale questions. The researcher recommended the importance of reviewing teaching plans and adding to them subjects related to fitness as well as activating the athletic activity theoretically and practically. 
Ulaimat et al., (1997) conducted a study that aimed at identifying the level of health culture among the 10th grade scientific branch students in Amman. The researchers used the descriptive approach. They used a test as the study tool made of (50) multiple choices items. The study sample was determined following the stratified cluster sampling manner in the private schools and Amman first and second directorates' schools. The results showed that health culture was of medium level for half of the female students. Moreover, there were statistical significant differences in the variable of specialty in favor of the scientific branch. The most prominent recommendation of the study was the importance of including health subject in the curriculums of all levels.

\subsection{Commenting over previous studies}

The researcher reviewed a number of previous studies that handled the topic of the current study or alike.

The study of Aburrub, (2016) that aimed at identifying sports culture and its relationship with the tendency toward participating in sports activities among the students of Al-Najah National University; both studies were similar in handling the topic of sports culture among universities' students, using the descriptive approach, applying a questionnaire as the study tool, the high level of sports culture, and the absence of statistically significant differences regarding the variable of gender. The current study was also similar to the study of Qadumi \& Al-'amd, (2017) - which aimed at identifying the level of sports culture and its relationship with the athletic identity among PE students at Al-Najah National University - regarding the level of sports culture among university students, using the descriptive approach, the tool of collecting data, and the high level of sports culture among the sample's members. It was also similar to the study of Ahmad \& Mahdi 2012 - which aimed at identifying sports culture and its relation to the social and psychological harmony among fifth-year-students in the Teachers Institute in the inspected domains (health, psychological, social, and cognitive domains). Studies varied when it came to the role of media in spreading sports culture awareness as the case was in the study of Al-'adwan, (2011) and the study of Lahlouh, (2017) as well as the study of Al-Rahahleh \& Mash'al, (2012) which handled the topic of identifying the cognitive outcome of nutritional culture and the level of aerobic fitness among the students of physical education at the University of Jordan. The researcher benefited from the previous studies regarding the statistical procedures that are used.

\section{Methodology and Procedures of the Study}

\subsection{Methodology of the Study}

The researcher used the descriptive approach for its suitability to this type of studies.

\subsection{Population of the Study}

The study population was made of the first, second and third-year-students at Al-Hussein Bin Talal University for the academic year 2017/2018; (3850) students, males and females, distributed over the university's scientific and humanitarian colleges. 


\section{Al Macrothink}

International Journal of Learning and Development

ISSN 2164-4063 2019, Vol. 9, No. 1

\subsection{Sample of the Study}

The study sample was composed of (214) students, males and females; have been chosen randomly composing (5.5\%) of the study population who didn't study the university's need of PE courses. Table 1 shows the characteristics of the sample members.

Table 1. The distribution of the study sample according to the variable of gender

\begin{tabular}{lll}
\hline Gender & Number & Percentage \\
\hline Males & 94 & 43.925 \\
Females & 120 & 56.075 \\
Total & 214 & 100 \\
\hline
\end{tabular}

\subsection{Tool of the Study}

In order to identify the level of sports culture among the students of Al-Hussein Bin Talal University and based on the theoretical literature, educational intellect, and the previous studies, the researcher developed a questionnaire as the tool of this study composed of (40) items divided into four domains; the cognitive domain (10) items, the social domain (10) items, the health domain (10) items, and the psychological domain (10) items, in an initial form.

\subsubsection{Validity of Attributors}

The study tool was tested by a group of specialized faculty members to verify the content's validity. Some items were amended; other four items have been excluded depending on the consensus of $75 \%$ of the attributors. Thus, the final form of the questionnaire was composed of (36) items divided into four domains (the cognitive, social, health, and psychological domains).

\subsubsection{Internal Consistency Validity}

The validity of the internal consistency of the scale have been verified through applying it over an exploratory sample composed of (36) students; from outside the study sample. Pearson correlation coefficient has been calculated regarding the score of each of the scale's domains as well as the total score of the scale. Table 2 shows this: 
Table 2. The correlation coefficient for each dimension of the scale with the total score of the scale

\begin{tabular}{ll}
\hline Domain & Correlation coefficient \\
\hline Cognitive & $082^{*}$ \\
Social & $0.80^{*}$ \\
Health & $0.79^{*}$ \\
Psychological & $0.71^{*}$ \\
\hline
\end{tabular}

* Statistically significant at $(\alpha=0.01)$.

Table (2) shows that regarding the total score, the domains are statistically correlated at $(\alpha=0.01)$. This confirms that the scale has a high level of reliability and internal consistency. Pearson correlation coefficient have been calculated for each item of the scale and for the total score of the domain to which the item belongs, this showed that all items are statistically correlated with the domain's total score which proves the validity of the internal consistency of the scale's items. Table (3) demonstrates this:

Table 3. The correlation of each item of the scale's items with total score of the dimension to which it belongs

\begin{tabular}{llll}
\hline Item no. & Correlation coefficient & Item no. & Correlation coefficient \\
\hline 1 & $0.63^{*}$ & 19 & $0.68^{*}$ \\
2 & $0.69^{*}$ & 20 & $0.64^{*}$ \\
3 & $0.67^{*}$ & 21 & $0.56^{*}$ \\
4 & $0.66^{*}$ & 22 & $0.64^{*}$ \\
5 & $0.57^{*}$ & 23 & $0.63^{*}$ \\
6 & $0.54^{*}$ & 24 & $0.63^{*}$ \\
7 & $0.70^{*}$ & 25 & $0.66^{*}$ \\
8 & $0.67^{*}$ & 26 & $0.49^{*}$ \\
9 & $0.56^{*}$ & 27 & $0.44^{*}$ \\
10 & $0.48^{*}$ & 28 & $0.47^{*}$ \\
11 & $0.54^{*}$ & 29 & $0.60^{*}$ \\
12 & $0.57^{*}$ & 30 & $0.56^{*}$ \\
13 & $0.60^{*}$ & 31 & $0.59^{*}$ \\
14 & $0.58^{*}$ & 32 & $0.57^{*}$ \\
15 & $0.68^{*}$ & 33 & $0.48^{*}$ \\
\hline
\end{tabular}




\begin{tabular}{llll}
\hline 16 & $0.70^{*}$ & 34 & $0.56^{*}$ \\
17 & $0.59^{*}$ & 35 & $0.41^{*}$ \\
18 & $0.59^{*}$ & 36 & $0.46^{*}$ \\
\hline
\end{tabular}

* Statistically significant at $(\alpha=0.01)$.

Table 3 shows that all the items are statistically correlated with the total score of the dimension.

\subsubsection{Reliability of the Scale}

The reliability of the scale has been verified through applying it over an exploratory sample from outside the study sample, composed of (36) students. Cronbach's Alpha coefficient has been applied to verify the reliability of the scale using the split half reliability. In order to eliminate the effect of split half, spearman brown formula has been relied on. Table (4) shows the reliability coefficient of the domains and the scale as a whole:

Table 4. The correlation coefficient of each dimension of the scale with the total score

\begin{tabular}{lll}
\hline Domain & Cronbach's Alpha coefficient & Split half reliability coefficient \\
\hline Cognitive & 0.82 & 0.76 \\
Social & 0.82 & 0.80 \\
Health & 0.69 & .063 \\
Psychological & 0.61 & 0.45 \\
Total & 0.90 & 0.82 \\
\hline
\end{tabular}

Table 4 shows that all the reliability coefficients are high.

\section{Results and Discussion}

To answer the study's questions, the respondents' answers to the items have been divided into three levels and each level is arbitrated according to the following criterion:

The category length $=$ the range / number of categories, based on this, three categories have been relied on:

1)- Less than 2.33 (low), 2- From 2.34 - less than 3.67 (medium), 3- From 3.68 and above (high).

First question: what is the level of sports culture among the students of Al-Hussein Bin Talal University?

To answer the first question, arithmetic means and standard deviations have been calculated for the study tool regarding the four domains of the study sample. The results were as shown in Table 5: 


\section{Macrothink}

International Journal of Learning and Development

ISSN 2164-4063 2019, Vol. 9, No. 1

Table 5. The arithmetic means and standard deviations of the four domains

\begin{tabular}{lllll}
\hline Domain & Arithmetic mean & Standard deviation & Order & Level \\
\hline Cognitive & 3.57 & 1.11 & 3 & Medium \\
Social & 3.94 & 1.01 & 1 & High \\
Health & 3.79 & 1.05 & 2 & High \\
Psychological & 3.41 & 1.24 & 4 & Medium \\
Total & 3.68 & 1.10 & & High \\
\hline
\end{tabular}

Table 5 shows that sports culture among the students of Al-Hussein Bin Talal University was of high level, where the total arithmetic mean was (3.68). The level of domains varied between high to medium as their arithmetic means ranged between $(3.94-3.41)$. The social domain came at the first rank with an arithmetic mean of (3.94) and a standard deviation of (1.01), whereas the psychological domain was at the last rank (forth rank) with an arithmetic mean of (3.41) and a standard deviation of (1.24). Moreover, the level of sports culture according to its domains among the university's students has been analyzed as shown in tables (6, 7, $8 \& 9)$.

\subsection{First: the Cognitive Domain}

The arithmetic means and standard deviations have been calculated for the level of sports culture among the students of Al-Hussein Bin Talal University regarding the cognitive domain. Table 6 shows this:

Table 6. The statistical analysis of the cognitive domain

\begin{tabular}{|c|c|c|c|c|}
\hline $\begin{array}{l}\text { Item } \\
\text { no. }\end{array}$ & Item & $\begin{array}{l}\text { Arithmetic } \\
\text { mean }\end{array}$ & $\begin{array}{l}\text { Standard } \\
\text { deviation }\end{array}$ & Level \\
\hline 10 & $\begin{array}{l}\text { I know that sport helps me to acquire proper } \\
\text { reasoning }\end{array}$ & 4.2710 & 0.96968 & High \\
\hline 6 & I am aware that sport is related to other sciences & 3.8178 & 1.02066 & High \\
\hline 3 & $\begin{array}{l}\text { I have knowledge about athletic skills in different } \\
\text { sport games }\end{array}$ & 3.7277 & 1.05107 & High \\
\hline 5 & I am aware that sport increases my physical abilities & 3.6714 & 1.11802 & High \\
\hline 8 & Sports develops my knowledge about useful life skills & 3.6636 & 1.02498 & Medium \\
\hline 1 & I have knowledge about the rules of different sports & 3.5234 & 1.09926 & Medium \\
\hline 4 & I am aware of sports injuries and protections & 3.4742 & 1.35825 & Medium \\
\hline 9 & $\begin{array}{l}\text { I know that practicing sports increases my ability to } \\
\text { focus and pay attention }\end{array}$ & 3.3602 & 1.11404 & Medium \\
\hline 2 & I have knowledge about the history of athletic games & 3.1822 & 1.12566 & Medium \\
\hline \multirow[t]{2}{*}{7} & $\begin{array}{l}\text { I have knowledge about the expertise opinions in } \\
\text { athletic games }\end{array}$ & 3.0376 & 1.24328 & Medium \\
\hline & Total & 3.58 & 1.11 & Medium \\
\hline
\end{tabular}




\section{MInstitute ${ }^{\text {Mink }}$}

Table 6 shows that sports culture among the students of Al-Hussein Bin Talal University regarding the cognitive domain was of medium level; with an arithmetic mean of (3.58) and a standard deviation of (1.11). The levels of the domain's items varied between medium to high; as the arithmetic means ranged between $(4.2710-3.0376)$. Item number (10) stating "I know that sport helps me to acquire proper reasoning" came at the first rank with an arithmetic mean of (4.2710) and a standard deviation of (0.96968), item (7) stating "I have knowledge about the expertise opinions in athletic games" came at the last rank with an arithmetic mean of (3.0376) and a standard deviation of (1.24328). Table (6) shows that four items $(10,6,5,3)$ were of high level due to the diversity of the cultural environment among the students as for the university offers full scholarships to students from outside the governorate which gives the opportunity for students from outside the governorate to join the university. The rest of the items were of medium level so do the total level of the sports culture for this domain, the researcher attributed this to the fact that students during their school years, they dedicate their time for studying and the school doesn't mind for sports culture or the athletic activities, in addition to using the time of PE classes for other subjects. Moreover, students at the university don't have compulsory subjects related to sports culture and students don't watch sports channel as for the university is located in a place where presenting these channels is not available. All this caused the medium level of sports culture regarding the cognitive domain among the students; on the other hand, students don't practice or follow athletic activities at the university as for the university doesn't have a major of physical education or this can be attributed to the lack of websites that students can watch to enhance their sports culture. These results comply with the study of (Bani Atta, 2009) and disagree with study of Aburrab, (2016) and the study of Al-Zayouz, (2013) due to the difference in the population and the sample of the study and the societal culture.

\subsection{Second: Social Domain}

Table 7. The statistical analysis of the social domain

\begin{tabular}{|c|c|c|c|c|}
\hline $\begin{array}{l}\text { Item } \\
\text { no. }\end{array}$ & Items & $\begin{array}{l}\text { Arithmetic } \\
\text { mean }\end{array}$ & $\begin{array}{l}\text { Standard } \\
\text { deviation }\end{array}$ & Level \\
\hline 18 & Sports makes me acquire proper leadership qualities & 4.1402 & 0.92892 & High \\
\hline 11 & $\begin{array}{l}\text { Practicing sports makes me acquire the ability to tolerate } \\
\text { people's different personalities }\end{array}$ & 4.1127 & 0.85588 & High \\
\hline 16 & $\begin{array}{l}\text { Monopolizing the broadcast of major world events deprives } \\
\text { some viewers from the right to watch }\end{array}$ & 4.0845 & 0.97729 & High \\
\hline 19 & $\begin{array}{l}\text { Practicing sports makes me work with the spirit of team } \\
\text { work }\end{array}$ & 4.0000 & 0.98819 & High \\
\hline 20 & I follow the world athletic games & 3.9720 & 0.96860 & High \\
\hline 17 & I visit the prominent sport attractions & 3.9486 & 0.99867 & High \\
\hline 14 & Sports develops the spirit of belonging to a team & 3.9439 & 1.03308 & High \\
\hline 12 & Practicing sports increases my interaction with others & 3.9159 & 1.06697 & High \\
\hline 15 & Sports enhances the concept of belonging to my homeland & 3.7009 & 1.09386 & High \\
\hline \multirow[t]{2}{*}{13} & Sports gives me good social qualities & 3.6075 & 1.22000 & Medium \\
\hline & Total & 3.9426 & 1.01315 & High \\
\hline
\end{tabular}




\section{Macrothink}

Table 7 shows that sports culture among the students of Al-Hussein Bin Talal University regarding the social domain was of high level; with an arithmetic mean of (3.9426) and a standard deviation of (1.01315). The items of the domain varied between high and medium where the arithmetic means ranged between (4.1402 - 3.6075). Item number (18) stating "Sports makes me acquire proper leadership qualities" came at the first rank with an arithmetic mean of (4.1402) and a standard deviation of (0.92892), Item (13) stating "Sports gives me good social qualities" came at the last rank with an arithmetic mean of (3.6075) and a standard deviation of (1.01315). Table (7) showed that all the items were of high level except for one item of medium level and the total level of sports culture for the social domain was of high level. The researcher attributed the high level of sports culture in the social domain to the fact that the university community is rich of the social interactions that form a hidden curriculum with several social outcomes such as cooperation, accepting others, and adapting with the surrounding environment. Moreover, physical activity provides them with good qualities reflected positively on building interactive social relations, acquiring social experiences, and enhancing working with a team spirit. As for students are aware that practicing sports increases their awareness toward social values that the society believes in and develops their social behavior. These results comply with the study of (Al-Qadoumi \& Al-'amd, 2017) regarding the very high level of sports culture; they also comply with the study of Aburrab, (2016) regarding the high level of sports culture among the students of Al-Najah National University, whereas the current study disagrees with the study of Bani Atallah, (2009) regarding the low level of sports culture in relation to the social domain where the researcher attributed this disagreement to the differences in the population and sample of the studies as for the current study's population was the students of the University of Jordan. The current study also disagreed with the study of Al-Zayoud, (2013) where in the social domain; the role of sports channels was of high level in spreading sports culture among the students of Yarmouk University due to the existence of a PE major in this university and the availability of sports equipment there.

\subsection{Third: Health Domain}

Table 8 . The statistical analysis of the health domain

\begin{tabular}{lllll}
\hline $\begin{array}{l}\text { Item } \\
\text { no. }\end{array}$ & Items & $\begin{array}{l}\text { Arithmetic } \\
\text { mean }\end{array}$ & $\begin{array}{l}\text { Standard } \\
\text { deviation }\end{array}$ & Level \\
\hline 27 & I practice sports because it develops my abilities & 4.0841 & 1.02203 & High \\
25 & I practice sports because it keeps me healthy & 4.0701 & 0.88267 & High \\
24 & $\begin{array}{l}\text { Women practicing sports gives them vitality and good } \\
\text { shape. }\end{array}$ & 4.0374 & 1.05639 & High \\
23 & I mind watching sports for athletes with special needs & 3.7850 & 1.10931 & High \\
28 & I care a lot for health and body building programs & 3.6854 & 1.08141 & High \\
26 & I practice sports because it enables me to practice healthy & 3.6308 & 1.04328 & Medium \\
& habits & 3.5869 & 1.14851 & Medium \\
21 & Sports develops my physical fitness & 3.2123 & 1.09165 & Medium \\
& I spend my free time practicing sports & 3.79 & 1.05441 & High \\
\hline
\end{tabular}




\section{Mll Macrothink}

International Journal of Learning and Development

ISSN 2164-4063 2019, Vol. 9, No. 1

Table 8 shows that the total level of health domain for the students of Al-Hussein Bin Talal University was high; with an arithmetic mean of (3.79) and a standard deviation of (1.05441). The items of the domain varied between high to medium and their arithmetic means ranged between (4.0841 - 3.2123). Item number (27) stating "I practice sports because it develops my abilities" came at the first rank with an arithmetic mean of (4.0841) and a standard deviation of (1.02203), item number (22) stating "I spend my free time practicing sports" came at the last rank with an arithmetic mean of (3.2123) and a standard deviation of (1.09165). Table (8) showed that items number $(27,28,23)$ were of high level and the items $(26,21,22)$ were of medium level, the researcher attributed the students' awareness of the effect of athletic activities over health and body in general to the fact that students at this age mind for beauty, fitness and body building; as for students look for information about being healthy and personal cleanness and they know that physical activity prevents diseases and it forms the first defensive line for their bodies so they keep away from fatness and extra weight and try to keep in shape. This study complies with the study of Khouyleh, (2016) were the health domain was of high level as well among supervisors who supervise their students health. It also agrees with the study of Aburrab, (2016) and the study of Bani Ata, (2009) where the level of health domain among the students of the University of Jordan was of good level, and the study of Khouyleh, (2016) regarding the high level of sports culture among the educational supervisors and maintaining their physical shape.

\subsection{Forth: the Psychological Domain}

Table 9. The statistical analysis of the psychological domain

\begin{tabular}{lllll}
\hline $\begin{array}{l}\text { Item } \\
\text { no. }\end{array}$ & Items & $\begin{array}{l}\text { Arithmetic } \\
\text { mean }\end{array}$ & $\begin{array}{l}\text { Standard } \\
\text { deviation }\end{array}$ & Level \\
\hline 33 & I encourage honest playing and I enjoy it & 3.7653 & 1.25191 & High \\
35 & Prejudice toward specific sports team is a wrong habit & 3.7290 & 1.30056 & High \\
34 & I enjoy following some technical moves in sports games & 3.7196 & 1.09882 & High \\
32 & Practicing sports makes me feel more confident & 3.6385 & 1.14752 & Medium \\
31 & Practicing sports helps me express myself & 3.4601 & 1.17142 & Medium \\
29 & $\begin{array}{l}\text { Practicing sports gives me the ability to be patient and } \\
\text { persistent }\end{array}$ & 3.1963 & 1.20593 & Medium \\
30 & Practicing sports help me control my nerves and stress & 3.1232 & 1.22045 & Medium \\
36 & I enjoy watching violence and riots at playgrounds & 2.7056 & 1.58700 & Medium \\
& Total & 3.4172 & 1.24795 & Medium \\
\hline
\end{tabular}

Table (9) shows that the total level of the psychological domain for the students of Al-Hussein Bin Talal University was medium with an arithmetic mean of (3.4172) and a standard deviation of (1.24795). The levels of the items of the domain varied between high to medium where the arithmetic means ranged between $(3.7653-2.7056)$. Item number (33) stating "I encourage 


\section{Macrothink}

honest playing and I enjoy it" came at the first rank with an arithmetic mean of (3.7653) and a standard deviation of (1.25191), item number (36) stating "I enjoy watching violence and riots at playgrounds" came at the last rank with an arithmetic mean of (2.7056) and a standard deviation of (1.58700). Table (9) showed that items number $(33,34,35)$ were of high level whereas items number $(32,31,29,30,36)$ were of medium level, the researcher attributed this to the fact that students are not properly aware of the impact of physical practice on the psychological dimension or its impact on enhancing self-confidence, knowing one's self, self-control, increasing one's patience and persistence. These results disagreed with the study of Bani Ata, (2009) where the psychological domain was of low level regarding sports culture among the students of the University of Jordan due to the variety of the activities held by the university in different cultural and social aspects.

The second question: Does the level of sports culture among university students differ according to the variable of gender?

To answer this question, the Independent Sample T test has been applied.

Table 10. The results of the statistical analysis of the sports culture based on gender

\begin{tabular}{llllllll}
\hline Variable & Group & Number & Arithmetic mean & Standard deviation & DF & T value & Sig. \\
\hline Gender & Male & 94 & 134.5 & 17.6 & 212 & 1.6 & 0.108 \\
& Female & 120 & 130.5 & 18.6 & & & \\
\hline
\end{tabular}

Table (10) shows that there are no statistically significant differences at $(\alpha=0.05)$ in the level of sports culture among the students of Al-Hussein Bin Talal University attributed to the variable of gender. The researcher attributes the absence of differences to the fact that students at the university are exposed to the same circumstances so the level of sports culture does not differ between males and females, this result sounds normal as for the surrounding circumstances and the nature of the region affect the students equally. This result complies with the study of Aburrab, (2016), the study of Al-Qadoumi \& Al-'amd, (2016) and the study of Khuayleh, (2013), whereas it disagrees with the study of Al-Zayoud, (2013) where the results showed that there are statistically significant differences in favor of males. The researcher attributes this disagreement to the difference in the study's population and sample as well as the possibility of practicing sports at Yarmouk University and the difference in the societal culture among universities.

The third question: Does the level of sports culture among university students differ according to the variable of college?

To answer this question, the Independent Sample T test has been applied. 


\section{Macrothink}

Table 11. The results of the statistical analysis of the sports culture based on types of collages, humanities and scientific

\begin{tabular}{llllllll}
\hline Variable & Group & Number & $\begin{array}{l}\text { Arithmetic } \\
\text { mean }\end{array}$ & $\begin{array}{l}\text { Standard } \\
\text { deviation }\end{array}$ & DF & T value & Sig. \\
\hline college & Humanitarian & 102 & 134.12 & 15.9 & 212 & 1.42 & 0.157 \\
& Scientific & 112 & 130.6 & 20.1 & & & \\
\hline
\end{tabular}

Table (11) shows that there are no statistically significant differences at $(\alpha=0.05)$ in the level of sports culture among the students of Al-Hussein Bin Talal University attributed to the variable of college. The researcher attributes the absence of these differences among the university's students whether in the humanitarian or scientific colleges to several reasons such as that students' circumstances at the university are similar and the availability of playgrounds and sports equipment is rare, as well as there is no stimulation for the students to practice sports, these results complied with ....... And disagreed with the study of Bani Ata, (2009) where the results showed that students of scientific colleges surpassed the students of humanitarian colleges, they also disagreed with the study of Al-Zayoud, (2013) where the results showed that there are statistically significant differences regarding the variable of college in favor of the scientific colleges due to the availability of sports facilities at Yarmouk University and the existence of physical education major which help students to practice sports. These results disagreed with the study of Lahlouh, (2017) as well, where the results showed that there are statistically significant differences according to the variable of college in favor of the humanitarian colleges.

\section{Conclusions}

1)- Students of Al-Hussein Bin Talal University have a high level of sports culture in the health and social domains.

2)- Students of Al-Hussein Bin Talal University have a medium level of sports culture in the cognitive and psychological domains.

3)- The level of sports culture among the students of Al-Hussein Bin Talal University doesn't differ between males and females.

4)- The level of sports culture among the students of Al-Hussein Bin Talal University doesn't differ between the scientific and humanitarian colleges.

\section{Recommendations}

1) - Promote the concept of sports culture through elective courses at the university, especially in the cognitive and psychological domains.

2) - Encourage students to participate in sports activities at the university and form sports teams from different colleges.

3) - Encourage female students to participate and exercise sports at the university. 
4) - Provide sports facilities at the university and allocate specific time for females.

5) - Hold courses and sports conferences to spread the athletic awareness among students at the university.

6) - Conduct studies and researches in other areas on the students of Al-Hussein University due to the lack of research applied on this university.

\section{References}

Abd Al-Ati, A., \& Abd Al-Haleem. (2000). A philosophical model of physical education curriculum in the arab-islamic culture race. Dar Elfikr Elarabi, First Edition; Cairo.

Aburrab. I. (2016). Sports culture and its relationship with the students' tendency towards the participation in athletic activities at al-najah national university. Unpublished master thesis. Al-Najah National University; Nablus, Palestine.

Ahmad, M., \& Ismael, M. (2012). Sports culture and its relation to the social and psychological harmony among fifth-phase-students in the teachers' institute. Magazine of sports education. University of Diyala; Iraq.

Al-Adwan, M. (2001). The role of Jordanian TV in increasing sports culture from the perspective of sports collages students at the Jordanian universities. unpublished master thesis. Middle East University, Media College.

Al-Ramihi, M. (1992). The culture's reality and its future. The main documents of the UNESCO declaration on culture. Center of Arab Unity Studies.

AlZayoud, K. (2013). The role of watching sports TV channels in spreading sports culture among the students of yarmouk university. Islamic University Journal of Educational and Psychological Studies, 11(4) 321-345.

Bahbahani, B. (1997). The Cultural Scientific Encyclopedia; Kuwait.

Bani Ata, A. (2009). Measuring the Cognitive Level of Sports Culture among the Students of the University of Jordan. Mutah for research and studies, the series of humanitarian and social sciences, 24(1).

Cornelius, A. (1995). The Relationship between Athletic Identity, Peer and Faculty Socialization and College Student Development. Journal of College Student Development, 36, 560-573.

Filali, S. (2014). The Structure of Algerian Identity in the Shadow of Globalization. Unpublished PhD thesis. Mohamed Khider University; Biskra.

Khuayleh, K. (2016). The Level of Sports Culture among the Educational Supervisors in the Ministry of Education. The $11^{\text {th }}$ Conference of Physical Education College; University of Jordan and the $3^{\text {rd }}$ of Association of Arab Colleges of Physical Education in Sports Sciences.

Kush, D. (2002). The Concept of Culture in Social Sciences. Translated by Qasem Al-Miqdad, from the publications of the Arab Writers Union; Damascus. 


\section{Macrothink}

International Journal of Learning and Development

ISSN 2164-4063 2019, Vol. 9, No. 1

Lahlouh, S. (2017). The Role of Media in Spreading Sports Culture among the Palestinian Universities' Students in the West Bank. Unpublished master thesis. Higher Education Collage, Al-Najah National University; Nablus, Palestine.

Mash'al, M., Al-Rahahleh, A., \& Batayneh, M. (2012). The Cognitive Outcome of Nutritional Culture and the Level of Aerobic Fitness among the Students of Physical Education at the University of Jordan. Educational Sciences Studies, 39(2), Amman.

Qadoumi, M., \& Al-'amd, S. (2017). The Level of Sports Culture and its Relationship with the Athletic Identity among the Students of Physical Education at Al-Najah National University. Al-Najah University Journal for Research (humanitarian sciences), 31(1), Palestine.

Sadeq, G. M. (1990). Fundamentals of Education and Physical Education. Bagdad. Dar Al-Hikma for publication; Iraq.

Shahada, O. M. (2009). The Impact of Watching Sports Channels in Spreading the Sports Culture among the Students of the University of Diyala. Unpublished master thesis. Faculty of physical education, University of Diyala; Iraq.

Ulaymat, M., Waham, F., \&Ulaimat, A. (1997). The level of Health Culture among the Tenth Grad Female Students in Jordan..Al-Manarah Journal, 2(2).

\section{Copyright Disclaimer}

Copyright for this article is retained by the author(s), with first publication rights granted to the journal.

This is an open-access article distributed under the terms and conditions of the Creative Commons Attribution license (http://creativecommons.org/licenses/by/4.0/). 